\title{
Daughter of Venice: Caterina Corner, Queen of Cyprus and Woman of the Renaissance. Holly S. Hurlburt. \\ New Haven: Yale University Press, 2015. xi +348 pp. $\$ 85$.
}

This book offers proof that history is not stranger, but more inventive than fiction. What mere poet could have created Caterina Corner? Like Venice itself, she bridged East and West, land and sea, Greek and Latin, the swashbuckling imperialism of the medieval stato da mar and the cultivated leisure of the High Renaissance. In 1472, she journeyed to the island of Cyprus, but 200 miles west of Damascus, though 1,300 east of Venice. Four years earlier, she had been married by proxy to the last Lusignan king, Jacques II (r. 1464-73), the descendant of Frankish crusaders who held lands from Jerusalem to Armenia and had acquired the island by purchase in the twelfth century. Within ten months of her arrival, she gave birth to a son, born to reign as Jacques III. But the child soon died, and so had his father, some thirteen months before. In 1474, just twenty years old, Caterina Corner ruled as the widowed and childless foreign queen of the strategically vital island of Cyprus, propped up by Venetian admirals while the Ottoman threat loomed on the one hand, a Mamluk threat on the other, and a host of opportunists plotted to unseat her. At last, in 1489, persuaded by the emissary Venice had dispatched-Zorzi Corner, her own brother-reluctantly, she abdicated. Her unwilling surrender of the crown was read by the world as a noble act of renunciation.

So Caterina Corner now journeyed west, to the metropolis that had recently won for itself a stato da terra. Reunited with her family, Caterina Corner devoted herself to consolidating her wealth, the spoils of her imperial adventure, and promoting the interests of the Corner family — above all its patriarch, her brother Zorzi, who years after her death, while planning his sister's grandiloquent memorialization and the advancement of the Corner clan, fecund in cardinals and doges, was still extracting from Cyprus the payments owed the ousted queen.

Meanwhile, while she still lived, Caterina was an oddity in Venice: a queen in a republic! That oddity was captured in Gentile Bellini's portrayal of the Miracle of the True Cross at the Ponte San Lorenzo (1500)_like Caterina herself, adventitiously, the relic had come from Cyprus - explored at length by Hurlburt. Lined up along the side of the canal to observe the miraculous rescue are eleven identically postured women, accoutered in diaphanous linen and precious pearls: Caterina Corner and her attendants. Their conspicuous and ponderous presence underscores the incongruity of Corner's role in Venice: a foreigner yet a native, a queen and yet a participant in a peak moment of civic ritual. 
Those who held the cards did what they must: they got her out of town, and gave her a kingdom of her own, the hilltop domain of Asolo, set apart but not so far away it could not be surveilled. Here she established a miniature court, less grandiose but more refined than those of Famagusta or Nicosia. Here, if only in the imagination of Pietro Bembo, poets and philosophers gathered for elegant conversation in the limpid vernacular he had devised, as documented in his Asolani (The Asolans, 1505), the forerunner as a representation of the courtly ideal of Castiglione's Courtier, set in Urbino just a few years later. In this setting, Caterina Corner was once again a queen. And if Asolo became tedious, she could escape the congestion by resorting to the Barco, a luxury hunting lodge outside the city walls, its porticoes adorned with images of fanciful marine creatures, souvenirs of her lost maritime dominion, as was each vacant stone or plaster surface with the intertwined arms of Corner and Lusignan.

Hurlburt has written a book that needed to be written about a person who encapsulates the experience of Renaissance Venice. It is largely descriptive-no, it is all description. The author describes the island of Cyprus; the personnel of the court; its mélange of ethnicities, religions, and languages; its processions and rituals; and, in Venice, the Corner palace and monuments, nearby Asolo and its Barco, and architecture, images, and books. This is description by a resourceful investigator, deeply knowledgeable in both the culture and political histories of Venice that are here expertly knit together. Many of the artifacts and places described appear in the book, filling sixty-eight figures adorning just 235 pages of text, conspicuous among them sumptuous manuscript pages of works written in celebration of Caterina Corner. The book in which they appear is in itself a luxury object-kudos to Yale University Press - a thing of ebullient color and crisp black type on silky pages that beg to be stroked. All this befits a woman depicted bearing a pert golden crown (like the one sported by the Lusignan's rampant lion) even after that crown had been surrendered to the state that demanded her abdication; for hers was a perpetual coronation. The woman beneath the crown is no gauzy goddess or Neoplatonic figment, but sturdy and fleshy in her mute declaration of self-worth. Christlike, she is incarnate, the embodiment of Venice, retrieved from the mists of legend; Christlike, she is a redeemer, who suffered and sacrificed. She is Venice, and Venice, that archipelago of manly black-robed councillors, was a woman.

Margaret L. King, Brooklyn College and The Graduate Center, CUNY, emerita 